\title{
First report on histology and ultrastructure of an intrahemocytic paramyxean parasite (IPP) from tunicate Halocynthia roretzi in Korea
}

\author{
Dong Lim Choi ${ }^{1, *}$, Bo Young Jee ${ }^{1}$, Hee Jung Choi ${ }^{1}$, Jee Youn Hwang ${ }^{1}$, \\ Jin Woo Kim ${ }^{1}$, Franck C. J. Berthe ${ }^{2}$
}

${ }^{1}$ Pathology Division, National Fisheries Research and Development Institute, 408-1 Silang, Gijang, Busan 619-902, Republic of Korea

${ }^{2}$ Department of Pathology \& Microbiology, Atlantic Veterinary College, UPEI, 550 University Ave., Charlottetown Prince Edward Island C1A 4P3, Canada

\begin{abstract}
In 2004, epizootiological studies were conducted on mass mortalities of tunicates Halocynthia roretzi in Goje, Korea. The clinical characteristics of infected H. roretzi were weakness of the tunic, loss of elasticity, and finally death involving a rupture of the tunic. Histological studies revealed severe hemocyte infiltration in the connective tissue surrounding the intestine and mantle of infected H. roretzi. Hypertrophied eosinophilic hemocytes containing several cytoplasmic vacuoles were observed in the connective tissue surrounding the intestine, gill and mantle. Ultrastructural examination revealed the presence of a parasite in the cytoplasm of hemocytes. Secondary cells were observed in the primary cell of the parasite. Spore formation within primary cells suggests that the parasite may be an intrahemocytic paramyxean parasite (IPP) and may cause mass mortality of $H$. roretzi.
\end{abstract}

KEY WORDS: Intrahemocytic paramyxean parasite $\cdot$ Tunicate $\cdot$ Halocynthia roretzi $\cdot$ Histology Ultrastructure

\section{INTRODUCTION}

Paramyxeans, a group of protistan parasites that infect marine invertebrates and cause significant diseases in cultured marine molluscs, are characterized by the formation of spores. These spores consist of several cells, enclosed inside one another, which result from the internal cleavage of a stem cell (Desportes \& Perkins 1990). In the phylum Paramyxea, species of the genus Marteilia and Marteilioides have been extensively studied because of the detrimental effect they have on commercially exploited bivalves.

Marteilia refringens has caused recurring mortalities in flat oysters Ostrea edulis from France, Spain and Portugal since its discovery in 1968 (Grizel et al. 1974, Alderman 1979, Figueras \& Montes 1988, Robert et al. 1991). M. sydneyi, the causative agent of the
QX (Queensland Unknown) disease, is responsible for mortalities of Saccostrea commercialis in Australia. M. sydneyi may be distinguished from $M$. refringens by the number of secondary and tertiary cells in the characteristic cell-within-cell structure of these parasites. M. maurini was described from Mytilus galloprovincialis from Venice Lagoon and was imported into France (Comps et al. 1982), later infecting Mytilus edulis in Brittany, France (Affret \& Poder 1983). Molecular evidence of the 2 species showed that Marteilia refringens and $M$. maurini can co-infect both oysters and mussels but that such infections were rare and only occurred in areas where prevalence of both parasites was high (Le Roux et al. 2001). Marteilioides chungmuensis is known to cause ovarian enlargement in Crassostrea gigas from Korea and Japan (Seki 1934, Chun 1979, Comps et al. 1986, Itoh et al. 2002, Park et al. 2003). 
Halocynthia roretzi is an important aquaculture species in Korea and Japan. It is an edible tunicate as well as a source of collagen. Mass mortalities of $H$. roretzi have occurred over the last 2 decades along the southern and eastern coasts of Korea causing serious economic damage.

Mortalities of more than $50000 \mathrm{t}$ of cultured Halocynthia roretzi were reported from Korea in 2003, and this occurence was the incentive for the present epidemiological study. Diseases causing mortalities in urochordates have rarely been reported (Monniot 1990). In the present study, we describe histological and ultrastructural characteristics of an intrahemocytic paramyxean parasite (IPP) that is associated with the mass mortality of $H$. roretzi. This paper provides the first description of an IPP infecting the hemocytes of edible tunicates $H$. roretzi cultured on the southern coast of Korea.

\section{MATERIALS AND METHODS}

Tunicates $(\mathrm{n}=30)$ Halocynthia roretzi 1 to $2 \mathrm{yr}$ old were collected from private aquaculture farms located in Goje, Korea, in June 2004.

Histological examination. Halocynthia roretzi tissues were fixed in Davidson's solution (Howard \& Smith 1983), processed for paraffinembedding and cut into $4 \mu \mathrm{m}$ thick sections. Sections were stained with Harris's hematoxylin and eosin (H\&E) for light microscopy examination.

Ultrastructural examination. Halocynthia roretzi tissues were fixed in $2.5 \%$ glutaraldehyde in $0.2 \mathrm{M}$ cacodylate buffer at $\mathrm{pH} 7.2$ for $1 \mathrm{~h}$ at $4^{\circ} \mathrm{C}$. After 2 washes in cacodylate buffer, the tissues were post-fixed in osmium tetroxide in the same buffer at $4^{\circ} \mathrm{C}$. Samples were dehydrated through graded alcohols, rinsed twice for $15 \mathrm{~min}$ in propylene oxide, and embedded in Epon resin compound (Ouken). Semi-thin sections $(200 \mu \mathrm{m})$ were stained with toluidine blue, and ultra-thin sections $(60 \mu \mathrm{m})$ were stained with uranyl acetate and lead citrate. Ultra-thin sections were carefully examined with a Hitachi 7100 transmission electron microscope at $80 \mathrm{kV}$.

\section{RESULTS}

Thirty tunicates Halocynthia roretzi were collected from Goje, Korea, and used for histological and ultrastructural analysis. Infected tunicates characteristically possessed a thin tunic
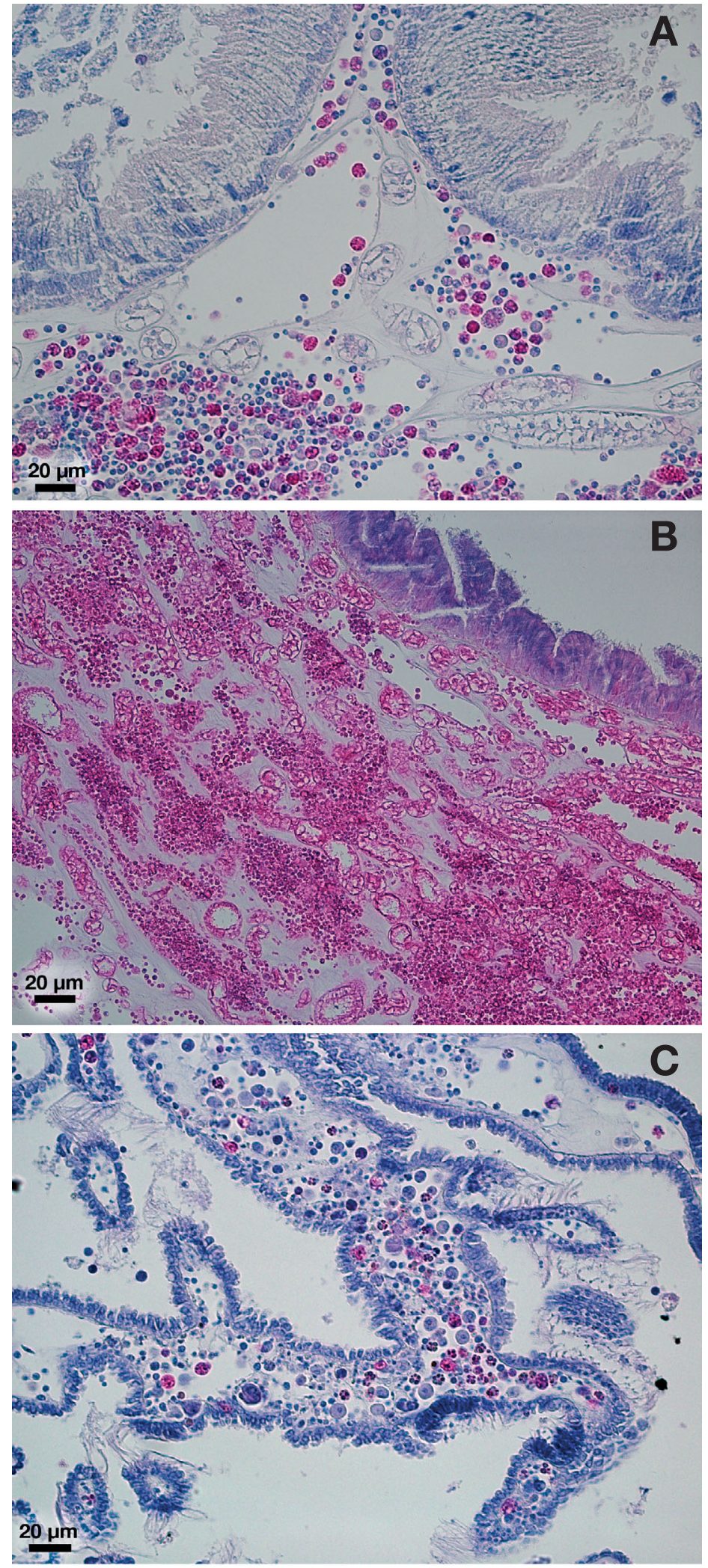

Fig. 1. Halocynthia roretzi. H\&E-stained section of connective tissue surrounding the (A) hepatopancreatic tubules, (B) mantle, and (C) gill. Numerous hemocytes have infiltrated the tissues 
that lost elasticity with disease progression. Moribund tunicates had a bad odor, became flaccid and finally died due to a rupture of the tunic.

Histological observations of infected tunicates, in the connective tissues surrounding the intestines and digestive diverticula as well as the mantle and gill tissues, showed severe hemocyte infiltrations (Fig. 1). Within the hemocytic infiltrate, enlarged hemocytes were observed that contained several vacuoles in the cytoplasm (Fig. 2). Affected hemocytes were eosinophilic, suggesting that they were either granular leukocytes or pigment cells. These were also observed in gill and mantle tissues.

Electron microscopy showed infection within enlarged hemocytes scattered in the connective tissues of the intestine and digestive diverticula. The earliest stage was a primary cell of the parasite which was found in the cytoplasm of the hemocyte (Fig. 3). The shape of the primary cell $(n=4)$ was generally spheroid $(2.09 \pm 0.25 \mu \mathrm{m})$ and contained electron-dense material. The secondary cells developed from the primary cell by internal cleavage of the stem cell. The secondary cells contained a round electron-dense body and were enclosed by a membrane (Fig. 4). During sporulation, a high density of cytoplasmic ribosomes was found within the cytoplasm of infected hemocytes (Fig. 5). After maturation of the secondary cells the host nucleus was located peripherally (Fig. 6). The mature spore was round $(1.69 \pm 0.57 \mu \mathrm{m})(\mathrm{n}=30)$. The intracellular parasite was enclosed by a plasma

Fig. 2. Halocynthia roretzi. H\&E-stained section of mantle tissue Abnormally enlarged and eosinophilic hemocytes (arrows) are shown

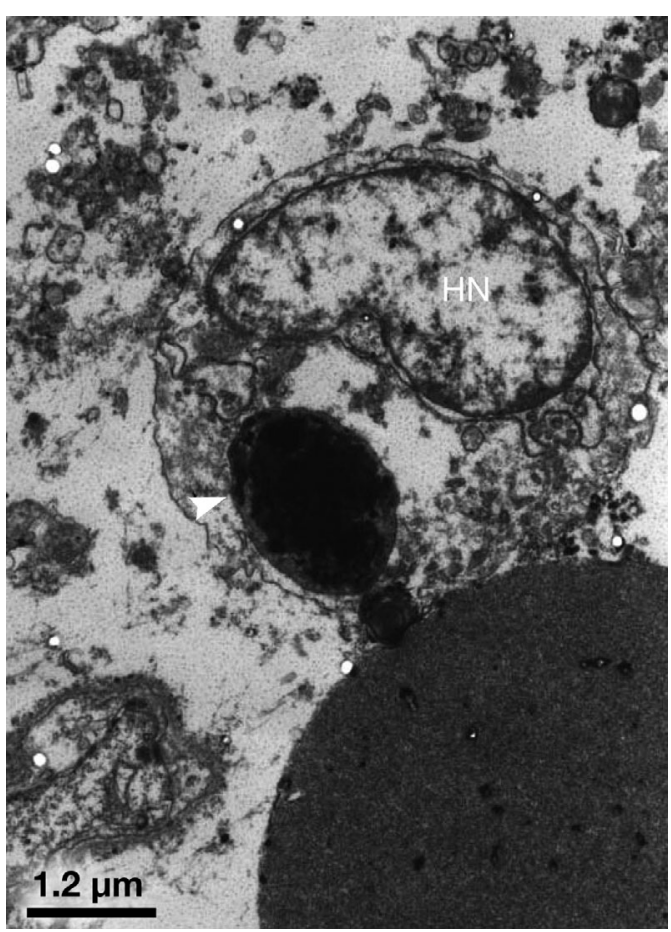

Fig. 3. Halocynthia roretzi. Transmission electron micrograph of a hemocyte showing earliest stage of a primary cell (arrowhead) adjacent to the nucleus (HN) of the host cell

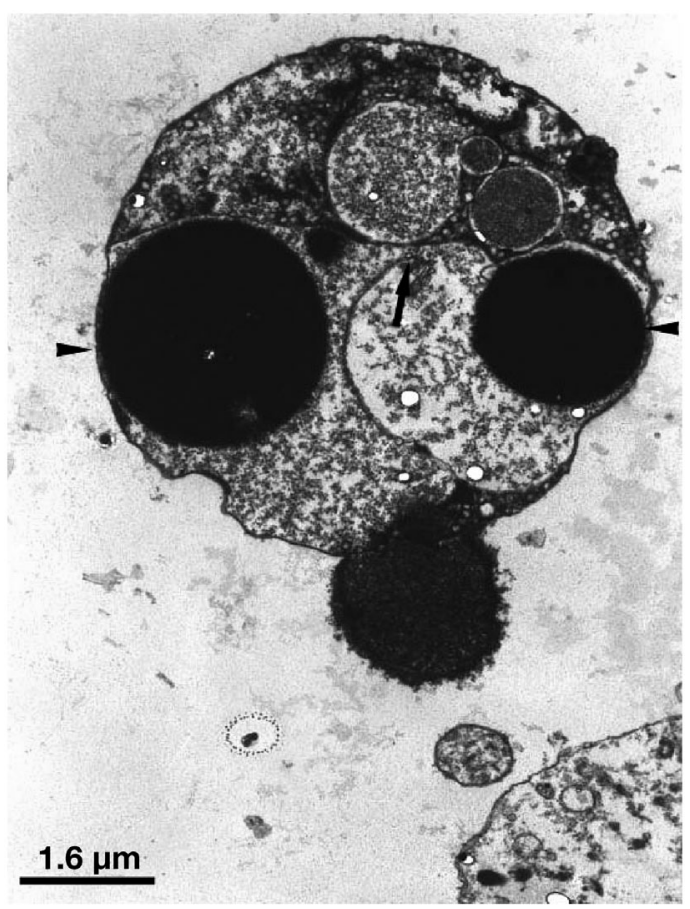

Fig. 4. Halocynthia roretzi. Transmission electron micrograph of hemocyte showing round electron-dense material of secondary cells (arrowheads) dividing a plasma membrane (arrow) within the secondary cell 


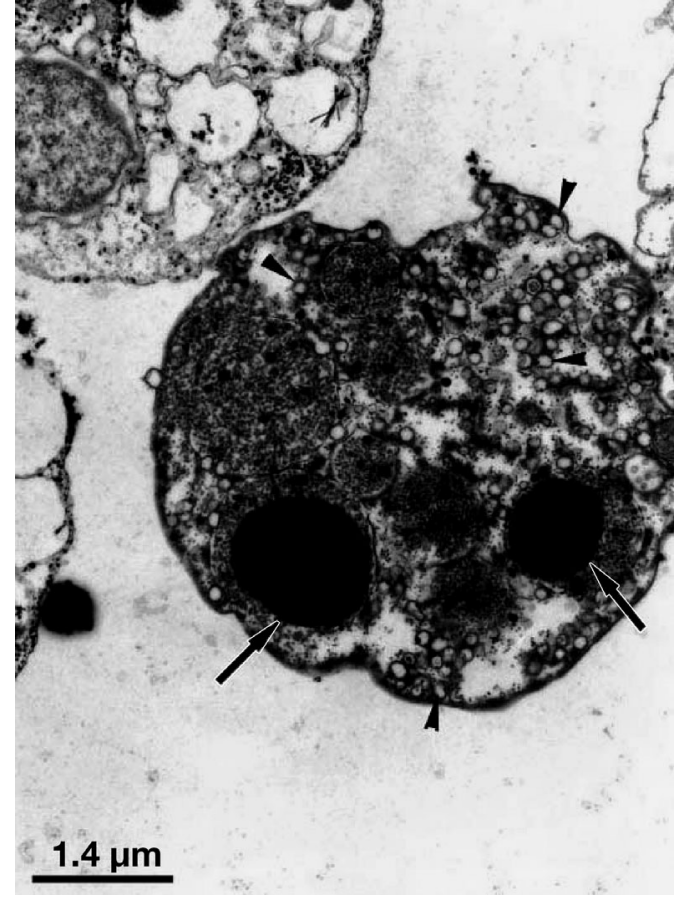

Fig. 5. Halocynthia roretzi. Transmission electron micrograph of hemocyte showing development of secondary cells (arrows) within the cytoplasm. Numerous small vacuoles in the cytoplasm of the hemocyte are shown (arrowheads)

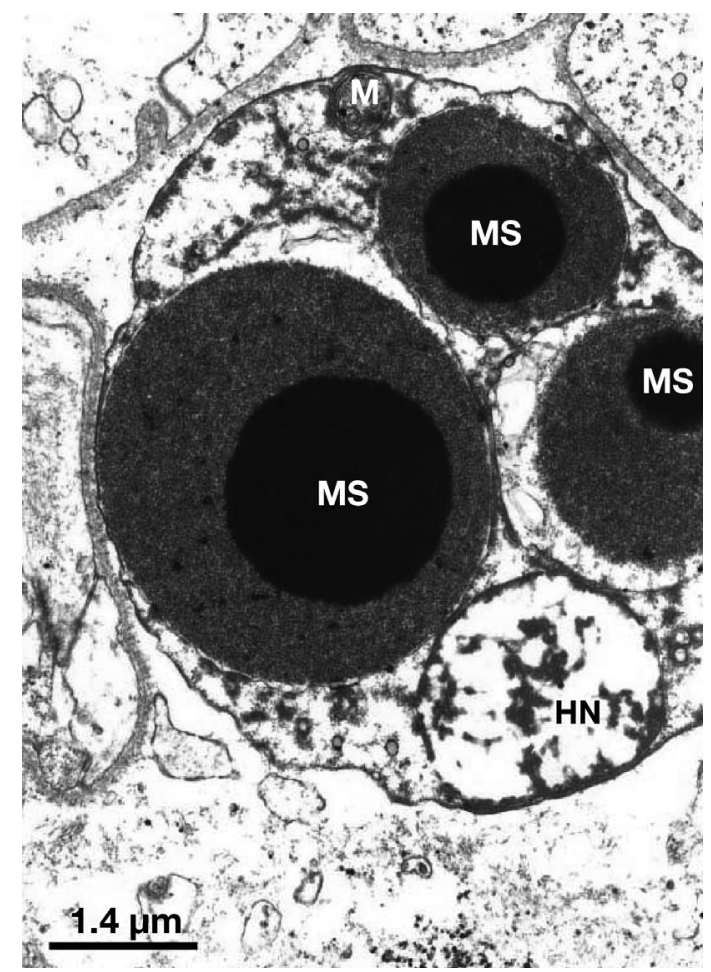

Fig. 6. Halocynthia roretzi. Transmission electron micrograph of hemocyte showing 3 mature spores (MS) forcing the nucleus (HN) to the margin of the host cell. M: mitochondria

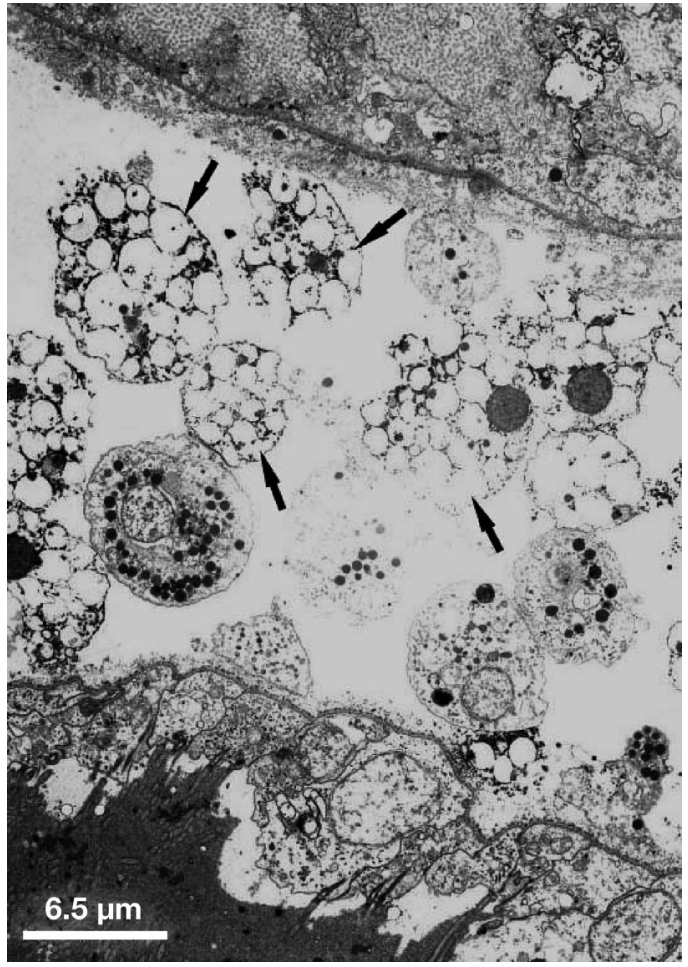

Fig. 7. Halocynthia roretzi. Degenerating and lysing hemocytes (arrows)

membrane and no internal structure was observed. After release of spores from hemocytes, the hemocytes, including many empty vacuoles, degenerated (Fig 7). Infection by the intrahemocytic paramyxean parasite was observed in all tunicates examined $(n=30)$.

\section{DISCUSSION}

In the present study we describe for the first time a paraxyxean parasite associated with the high mortality of the tunicate Halocynthia roretzi in Korea in 2004. When viewed using transmission electron microscopy the peculiar vacuoles within the enlarged eosinophilic hemocytes appeared as intracellular parasites. Infection was first recognized by the presence of a primary cell. Secondary cells were derived from the primary cell by internal cleavage of a stem cell within the hemocytes. This spore formation mechanism is characteristic of the Paramyxea Levine 1980. On the basis of the spore formation mechanism, we propose that this parasite is an IPP, although its classification has not yet been determined.

Tunicate blood cells, or hemocytes, display extensive polymorphisms (Burighel \& Cloney 1997). Hemocytes of Halocynthia roretzi participate in cellular defense reactions (Fuke 1980, Ohtake et al. 1994, Takahashi et 
al. 1994), humoral defense (Azumi \& Yokosawa 1996) and other biological functions such as excretion, nutrition, budding, germ cell formation and tunic synthesis (Goodbody 1974, Wright 1981, Burighel \& Cloney 1997). The IPP caused lysis and necrosis of $H$. roretzi hemocytes after release of mature spores. The kinds of hemocytes infected by the IPP could not be identified in this study. Nevertheless, the degeneration of $H$. roretzi hemocytes may provoke physiological disorders, tunic weakness and, finally, mortality.

Light and electron microscopy have several limitations when used to determine the taxonomic boundaries of these parasites (Comps et al. 1975, Tige \& Rabouin 1976, Affret \& Poder 1983). Sequencing genes of taxonomic value may help to determine the taxonomic position of IPPs. In addition, the use of DNA sequences, DNA probes and techniques such as in situ hybridization to identify the hemocyte type will prove invaluable in future studies of this parasite.

Acknowledgements. We thank Mr. Soonbae Kang of Pukyoung University, who provided technical assistance. This study was supported by the National Fisheries Research and Development Institute of Korea (Grant No. RP-2006-AQ-017)

\section{LITERATURE CITED}

Alderman DJ (1979) Epizootiology of Marteilia refringens in Europe. Mar Fish Rev 41:67-69

Auffret M, Poder M (1983) Recherches sur Marteilia maurini parasite de Mytilus edulis sur les côtes de Bretagne Nord. Rev Trav Inst Peches Marit 47(1-2):105-109

Azumi K, Yokosawa H (1996) Humoral factors and cellular reactions in the biological defense of the ascidian $H$. roretzi. In: Söderhäll K, Iwanaga S, Vasta G (eds) New directions in invertebrate immunology. SOS Publications, Fair Haven, NJ, p 43-53

Burighel P, Cloney RA (1997) Urochordata: Ascidiacea. In: Harrison FW, Ruppert EE (eds) Microscopic anatomy of invertebrates, Vol 15. Wiley-Liss, New York, p 221-347

Chun SK (1979) Amoeba infection in oyster (Crassostrea gigas). Bull Korean Fish Soc 12:281-285

Comps M, Grizel H, Tige G, Duthoit JL (1975) Parasites nouveaux de la glande digestive des mollusques marins Mytilus edulis L. et Cardium edule. C R Acad Sci Paris Ser D 281:179-181

Comps M, Grizel H, Papayanni Y (1982) Infection parasitaire causée par Marteilia maurini sp. nov. chez la moule Mytilus galloprovincialis. J Cons Int Explor Mer F:1-3

Editorial responsibility: Albert K. Sparks, Seattle, Washington, USA
Comps M, Park MS, Desports I (1986) Etude ultrastructurale de Marteilioides chungmuensis n. g., n. sp. parasite des ovocytes de l'huitre Crassostrea gigas Th. Protistologica 22:279-285

Desportes I, Perkins FO (1990) Phylum Paramyxea. In: Margulis L, Corliss JO, Melkonian M, Chapman DJ (eds) Handbook of Protoctista. Jones \& Bartlett, Boston, MA, p 30-35

Figueras AJ, Montes J (1988) Aber disease of edible oysters caused by Marteilia refringens. Am Fish Soc Spec Publ 18: $38-46$

Fuke MT (1980) 'Contact reactions' between xenogenic or allogeneic coelomic cells of solitary ascidians. Biol Bull (Woods Hole) 158:304-315

Goodbody I (1974) The physiology of ascidians. Adv Mar Biol 12:1-149

Grizel H, Comps M, Bonami JR,Cousserans F, Duthoit JL, Le Pennec MA (1974) Recherche sur l'agent de la maladie de la glande digestive de Ostrea edulis Linne. Bull Inst Peches Marit 240:7-30

Howard DW, Smith CS (1983) Histological techniques for bivalve mollusks. NOAA Tech Memo NMFSF/NEC-25:1-97

Itoh N, Oda T, Ogawa K, Wakabayashi H (2002) Identification and development of a paramyxean ovarian parasite in the Pacific oyster Crassostrea gigas. Fish Pathol 37:23-28

Le Roux F, Lorenzo G, Peyret P, Audemard C, Figueras A, Vivares C, Gouy M, Berthe F (2001) Molecular evidence for the existence of two species of Marteilia in Europe. J Eukaryot Microbiol 48(4):449-454

Monniot C (1990) Diseases of Urochordata. In: Kinne O (ed) Diseases of marine animals, Vol III. Biological Anstalt Helgoland, Hamburg, p 569-635

Ohtake S, Abe T, Shishikura F, Tanaka K (1994) The phagocytes in hemolymph of $H$. roretzi and their phagocytic activity. Zool Sci 11:681-691

Park MS, Kang CK, Choi, DL, Jee BY (2003) Appearance and pathogenicity of ovarian parasite Marteilioides chungmuensis in farmed Pacific oysters, Crassostrea gigas, in Korea. J Shellfish Res 22:475-479

Robert R, Borel M, Pichot Y, Trut G (1991) Growth and mortality of the European oyster Ostrea edulis in the Bay of Arcachon (France). Aquat Living Resour 4:265-274

Seki H (1934) The abnormal development of the oyster gonads in Hiroshima bay. Bull Jpn Soc Sci Fish 9:93-99

Takahashi H, Azumi K, Yokosawa H (1994) Hemocyte aggregation in the solitary ascidian Halocynthia roretzia: plasma factors, magnesium ion, and Met-Lys-Bradykinin induce the aggregation. Biol Bull (Woods Hole) 186: 247-253

Tige G, Rabouin MA (1976) Etude d'un lot de moules transferées dans un centre touché par l'epizootie affectant l'huitre plate. Proc ICES K:1-10

Wright RK (1981) Urochordates. In: Ratcliffe NA, Rowley AF (eds) Invertebrate blood cells, Vol 2. Academic Press, New York, p 565-626

Submitted: November 6, 2005; Accepted: June 21, 2006

Proofs received from author(s): September 7, 2006 